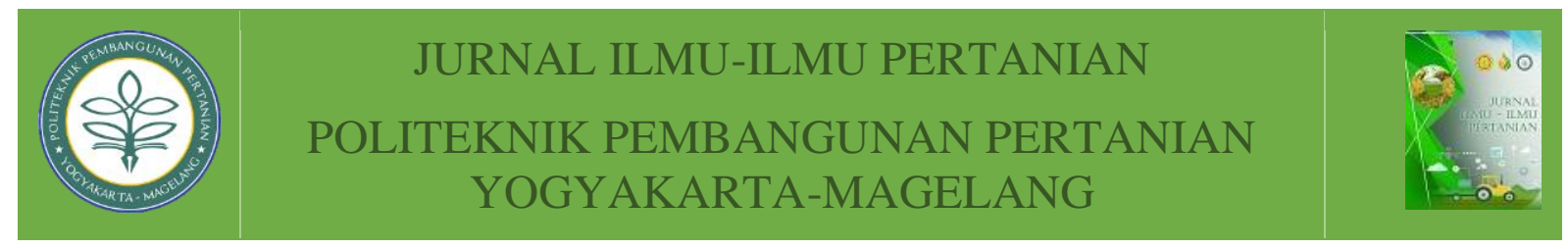

\title{
FAKTOR-FAKTOR YANG MEMPENGARUHI PENERAPAN PUPUK ORGANIK PADA BAWANG MERAH (Allium ascalonicum L) DI MURTIGADING SANDEN BANTUL
}

\author{
Sujono $^{1}$, Koeswini Tri Ariani ${ }^{2}$, Natsir $^{3}$ \\ ${ }^{1}$ Politeknik Pembangunan Pertanian Yogyakarta Magelang, Yogyakarta, 55167 \\ ${ }^{2}$ Politeknik Pembangunan Pertanian Yogyakarta Magelang, Yogyakarta, 55167 \\ ${ }^{3}$ Pemerintah Daerah Ende, NTT, 86319
}

Received
Accepted
Published
Copyright Notice
cc) (i)
: April 1 $1^{\text {st }}, 2021$

: $\quad$ May $3^{\text {rd }}, 2021$

: June $9^{\text {th }}, 2021$

: Authors retain copyright and grant the journal right of first publication with This work is licensed under a Creative Commons Attribution-Non Commercial 4.0 International License.

\begin{abstract}
ABSTRAK: Penelitian ini bertujuan untuk mengetahui factor-faktor yang mempengaruhi penerapan pupuk organik pada tanaman bawang merah. Kajian ini dilakukan di Desa Murtigading Kecamatan Sanden Kabupaten Bantul. Kajian dilakukan dengan mengumpulkan data primer responden kelompok tani. Penentuan Kecamatan, Desa dan Kelompok tani dilakukan secara purposive sedangkan pemilihan responden dengan proportional random sampling. Pengumpulan data dengan cara wawancara langsung dengan responden menggunakan panduan wawancara. Data yang diperoleh selanjutnya dianalisis dengan menggunakan analisis regresi linear berganda dengan aplikasi SPSS 23 for Windows. Hasil kajian menunjukan bahwa pengaruh faktor kepercayaan, ketersediaan pupuk, dan modal usaha secara bersama-sama berpengaruh nyata terhadap penerapan pupuk organik pada bawang merah ( $\left.F_{\text {hitung }} 5,039>F_{\text {tabel }} 2,056\right)$. Kontribusi $\left(R^{2}\right)$ keseluruhan variable X terhadap variabel Y sebesar 0,295 atau sebesar 29,5\% dan sisanya 70,5\% dipengaruhi oleh faktor diluar variabel penelitian (e). Faktorfaktor yang tidak berpengaruh nyata terhadap penerapan pupuk organik pada komoditas bawang merah adalah faktor kepercayaan, ketersediaan pupuk, dan modal usaha faktor ini nilai t hitungnya lebih kecil dari t tabel $\alpha n=26(2,056)$. Sedangkan faktor yang berpengaruh nyata terhadap penerapan pupuk organik pada komoditas bawang merah adalah faktor modal usaha tani, dimana faktor ini nilai thitungnya lebih besar dari t tabel $\alpha n=26(2,056)$.
\end{abstract}

Kata kunci: pengaruh; pupuk organik; bawang merah ;penerapan

ABSTRACT: This study aimed to determine the factors affecting the application of organic fertilizer on shallots (Allium ascalonicum L.) in Murtigading village, Sanden sub district Bantul regency. The study was conducted by collecting primary data respondent farmer groups. The determination of the district, village and farmer group purposely done while selecting respondents with proportional random sampling. The collection of data by direct interviews with respondents using a questionnaire. The data obtained were then analyzed using multiple linear regression analysis with SPSS 23 for Windows. The study results showed that the influence of trust, availability and stock

\footnotetext{
*sujono.jogja@gmail.com ${ }^{1}$
} 
farming together significantly affect the application of organic fertilizer on shallots $\left(F_{\text {count }} 5.039>F_{\text {table }}\right.$ 2.056 ). The contribution ( $\left.R_{2}\right)$ overall variable $X$ to variable $Y$ of 0.295 or $29.5 \%$ and the remaining $70.5 \%$ is influenced by factors beyond the study variables $(e)$. Factors that do not significantly affect the application of organic fertilizer on commodity onion is a trust factor and the availability of organic fertilizer which both these factors $T$ value is smaller than t table $\alpha n=26$ (2,056). While the factors that significantly affect the application of organic fertilizer on onion farming is capital factor, where this factor T value is greater than t table $\alpha n=26(2,056)$.

Keywords: Effect, organic fertilizer, onion, application

\section{PENDAHULUAN}

Indonesia merupakan daerah agraris yang menempatkan pertanian sebagai sektor sentral yang didukung oleh tersebarnya sebagian besar penduduk Indonesia yang hidup sebagai petani dan tinggal di pedesaan (Ayesma, 2014). Kecamatan Sanden adalah salah satu Kecamatan yang ada di Kabupaten Bantul Provinsi DIY, dengan komoditas andalan padi, jagung, cabe, dan bawang merah. Produktivitas Bawang Merah di Desa Murtigading Kecamatan Sanden selama lima tahun terakhir relatif stabil yaitu dengan rata-rata 11.25 ton/ha. Produktivitas Bawang Merah Desa Murtigading, total produksi bawang merah di kecamatan Sanden empat tahun terakhir adalah $495 \mathrm{kw} / \mathrm{ha}$. Sedangkan produktivitas bawang merah di Desa Murtigading berdasarkan programa BPP tahun 2018 mencapai 10,6 kwh/ha, lebih rendah dari tahun 2019 yaitu $11,3 \mathrm{kwh} / \mathrm{ha}$. Produksi belum stabil dan pernah mencapai 1.244 ton dan mengalami penurunan produksi 1.171 .

Penurunan nilai produksi bawang merah di Kecamatan Sanden tahun 2019 diduga dipengaruhi oleh kurangnya penerapan penggunaan pupuk organik pada komoditas bawang merah. Faktor yang menghambat produksi dan produktivitas pada tanaman bawang merah di Desa Murtigading, dipengaruhi oleh tingkat penerapan penggunaan pupuk organik antara lain, kepercayaan kualitas pupuk organik, bahwa petani belum yakin penggunaan pupuk organik dapat meningkatkan produktivitas bawang merah. Berdasarkan BPP Sanden (2019) baru $35 \%$ petani yang menggunakan pupuk organik di Desa Murtigading. Kebutuhan akan bahan, belum mencukupi kebutuhan petani bawang merah karena persediaan pupuk organik di desa terbatas, setiap rumah tangga petani tidak semua memiliki sapi sedangkan kotoran sapi sangat bermanfaat untuk bahan pembuatan pupuk organik. Berdasarkan Monografi Wilayah binaan khusus Desa Murtigading bahwa jumlah ternak sapi di Desa Murtigading sebanyak 620 ekor sapi potong. Penelitian yang dilakukan oleh Lawalata (2015) menunjukkan bahwa sebagian besar usahatani bawang merah di Kabupaten Bantul masuk dalam kategori kurang efisien, artinya tidak semua petani mampu memanfaatkan jumlah input minimum dari usahatani bawang merah yang diperlukan untuk menghasilkan output yang diinginkan, disebabkan persediaan pupuk organik terbatas. Penelitian yang dilakukan oleh Bahrul Ulum (2006) diketahui terdapat beberapa faktor yang menjadi pertimbangan dalam penggunaan pupuk organik diantaranya kualitas pupuk, ketersediaan pupuk. Hasil tersebut memberikan gambaran bahwa petani menggunakan pupuk organik tentunya didasari adanya kepercayaan kualitas pupuk dan ketersediaan atau kemudahan memperoleh pupuk organik sehingga dapat meningkatkan produktivitas hasil pertanian. Rekomendasi pemupukan Bawang merah di Kecamatan Sanden adalah urea $250 \mathrm{~kg} / \mathrm{ha}$, SP $100 \mathrm{~kg} / \mathrm{ha}$, ZA $250 \mathrm{~kg} / \mathrm{ha}$, NPK 100 $\mathrm{kg} / \mathrm{ha}$ dan organik $2.000 \mathrm{~kg} / \mathrm{ha}$. (BPP 
Kecamatan Sanden). Penggunaan pupuk organik untuk tanaman bawang merah oleh kelompok tani di Desa Murtigading $\pm 0,2$ ton/ha. Sedangkan rekomendasi pemupukan organik untuk budidaya bawang merah adalah 2 ton/ha. Ketidaktepatan jumlah pupuk organik yang digunakan, mengakibatkan rendahnya produktivitas lahan yang berpengaruh terhadap produktivitas dan mutu/kualitas dari bawang merah tersebut. Berdasarkan latar belakang tersebut, maka tujuan dari kajian ini adalah untuk mengetahui faktor-faktor yang mempengaruhi penggunaan pupuk organik pada tanaman bawang merah

\section{METODE}

Teknik pengambilan sampel pada penelitian ini adalah penentuan desa dipilih secara purposive sampling yaitu Desa Murtigading yang merupakan salah satu desa dengan cakupan sentra tanaman bawang merah dengan luasan lahan 1.244 ha serta memiliki kelompok tani yang kritis dan aktif. Penentuan kelompok tani sebagai sampel dipilih secara purposive sampling yaitu 10 (sepuluh) kelompok tani yaitu Sri Makmur, Taniku Maju, Sido Makmur, Lestari, Subur Makmur, Ngudi Rejeki, Sorono Mulyo, Ngudi Mulyo, Pucanganom II dan Tani Raharjo dari 10 kelompok tani yang ada dipilih 5 (lima) kelompok tani adalah Ngudi Mulyo, Taniku Maju, Pucanganom II, Ngudi Rejeki dan Sri Makmur untuk dijadikan penentuan sampel. Penentuan ke 5 (lima) kelompok tani berdasarkan luas lahan di atas 19 ha dengan pertimbangan bahwa kelompok tani tersebut lebih maju dalam usaha taninya. Jumlah total petani dari 5 (lima) kelompok tersebut adalah 272 orang. Pengambilan sampel petani responden dalam anggota kelompok tani dengan cara proportional random sampling (Nasir, 1985 : 355). Penelitian ini menggunakan analisis regresi linier ganda untuk mengetahui factor-faktor yang mempengaruhi penerapan pupuk organik pada tanaman bawang merah. Variabel $\mathrm{X}$ pada penelitian ini meliputi kepercayaan, ketersediaan pupuk, dan modal usaha tani, sedangkan variabel $\mathrm{Y}$ adalah penerapan pupuk organik pada bawang merah.

Rumusan umum fungsi regresi untuk mengetahui apakah variabel-variabel independen (X1, X2, X3) secara parsial atau secara individu berpengaruh atau tidak terhadap variabel dependen (Y) maka digunakan uji $t$ dengan taraf nyata (a) $5 \%$ dengan langkah pengujian menentukan Hipotesis Ho : Secara parsial variabel bebas (Xi) tidak berpengaruh nyata terhadap variabel terikat (Y).Ha : Secara parsial variabel bebas (Xi) berpengaruh nyata terhadap variabel terikat (Y). Menentukan taraf nyata dimana taraf nyata $(\alpha)=5 \%$,menentukan $\mathrm{t}$ hitung, $\mathrm{t}$ hitung diperoleh dari hasil pengolahan data menggunakan SPSS. Kriteria pengujian Ho diterima jika thitung $\leq \mathrm{t}$ tabel Ho ditolak jika $\mathrm{t}$ hitung $>\mathrm{t}$ tabel. Menentukan $\mathrm{t}$ tabel, tabel distribusi t dicari pada $\mathrm{a}=5 \%$ : $2=2,5 \%$ (uji 2 sisi) dengan derajat kebebasan (df) n-k-1. Keputusan jika nilai $\mathrm{t}$ hitung $\leq \mathrm{t}$ tabel maka Ho diterima, artinya variabel bebas tidak berpengaruh nyata terhadap variabel terikat. Jika nilai $\mathrm{t}$ hitung >t tabel maka Ho ditolak, artinya variabel bebas berpengaruh nyata terhadap variabel terikat.

\section{HASIL DAN PEMBAHASAN}

Untuk mengetahui faktor - faktor yang mempengaruhi penerapan petani terhadap pupuk Organik pada tanaman bawang merah digunakan analisis regresi linear berganda dimana variabel independen meliputi kepercayaan, ketersedian pupuk organik dan modal usaha tani variabel dependen yaitu penerapan pupuk organik pada bawang merah. Kontribusi secara bersama -sama antara variabel kepercayaan, ketersedian pupuk dan modal usaha tani terhadap tingkat penerapan pupuk organik pada tanaman bawang merah. 
Tabel 1. Kontribusi variabel kepercayaan, ketersedian pupuk dan modal usaha tani terhadap penerapan pupuk Organik.

Model Summary

\begin{tabular}{lccc}
\hline Model & R Square & Adjusted R Square & Std.Error Of the estimate \\
1 & .606 & .368 & 3.817 \\
\hline
\end{tabular}

Sumber : analisis data primer

Dari tabel 1 diatas dapat dilihat bahwa nilai dipengaruhi oleh faktor diluar penelitian (e) misalnya kontribusi secara keseluruhan variabel independen (kepercayaan, ketersedian pupuk dan modal usahatani) terhadap penerapan pupuk Organik (Y) sebesar 0,295 atau $29,5 \%$ dan yang tersisa $70,5 \%$ pendidikan dan usia. Pengaruh secara bersama Variabel Kepercayaan, ketersedian pupuk organik dan Modal usaha tani (X1, X2 dan X3) terhadap penerapan (Y) dapat dilihat pada tabel anova berikut

Tabel 2. Pengaruh variabel kepercayaan, ketersedian pupuk dan modal usaha tani terhadap penerapan pupuk Organik pada tanaman bawang merah

\begin{tabular}{|c|c|c|c|c|c|}
\hline \multicolumn{6}{|c|}{ ANOVA } \\
\hline Model & Sig & Sum of Square & Df & Mean Square & $\mathrm{F}$ \\
\hline 1 Regression & 0,007 & 220.294 & 3 & 73.431 & 5.039 \\
\hline $\begin{array}{c}\text { Residual } \\
\text { Total }\end{array}$ & $\begin{array}{l}78.906 \\
599.200\end{array}$ & 29 & 26 & 14.573 & \\
\hline
\end{tabular}

Dari tabel Anova diatas, nilai f hitung 5,039 lebih besar dari f tabel $\alpha 0,05$ df $3 / 26(2,056)$, maka dapat diartikan bahwa variabel independen kepercayaan, ketersediaan pupuk, dan modal usaha tani (X1, X2 dan X3) secara bersama dapat berpengaruh nyata terhadap variabel dependen tingkat penerapan pupuk Organik pada tanaman bawang merah. Pengaruh secara bersama Variabel Kepercayaan, ketersedian pupuk organik dan Modal usaha tani (X1, X2 dan X3) terhadap penerapan (Y) dapat dilihat pada tabel anova berikut :

Tabel 3. Pengaruh variabel kepercayaan, ketersedian pupuk dan modal usaha tani terhadap penerapan pupuk Organik pada tanaman bawang merah

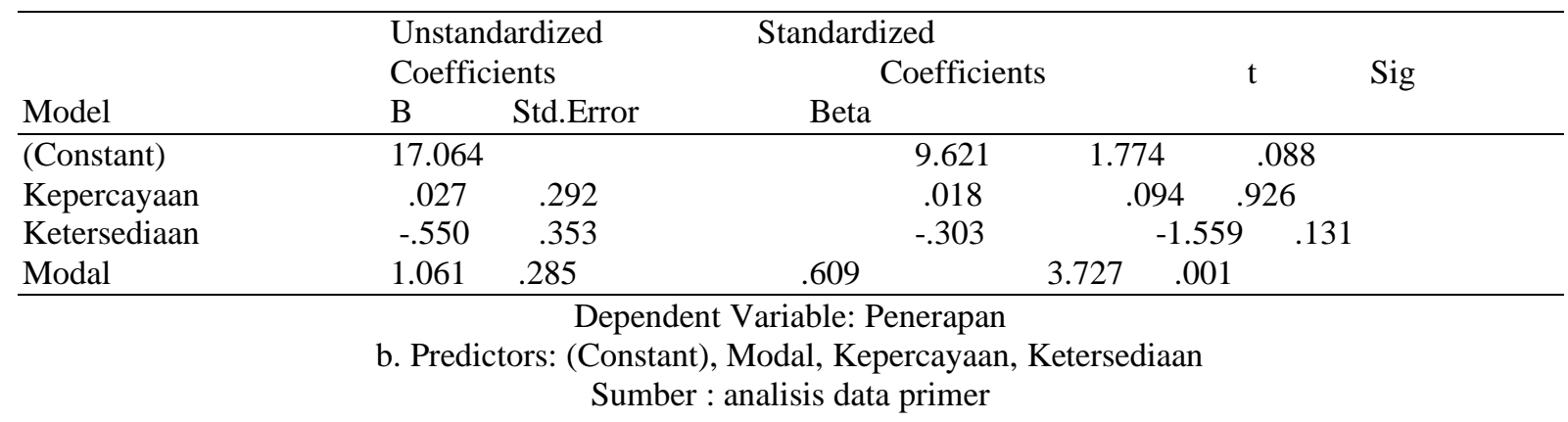

Dari table 3. koefisien dapat dilihat bahwa pengaruh secara sendiri antara variabel kepercayaan, ketersediaan pupuk dan modal terhadap variabel penerapan, variabel kepercayaan (X1) Nilai koefisien kepercayaan (X1) sebesar 0,018 artinya 
setiap penambahan satu satuan pengalaman tentang penerapan pupuk organik pada tanaman bawang merah maka akan menambah kepercayaan sebesar 0,018satuan. Uji signifikan dengan menggunakan uji-t terhadap koefisien variabel kepercayaan (X1) didapat $\mathrm{t}$ hitung sebesar 0,094 lebih kecil nilai ttabel $\mathrm{n}=26(2,056)$, artinya variabel kepercayaan (X1) tidak berpengaruh terhadap penerapan pupuk organik pada tanaman bawang merah, sehingga variabel kepercayaan (X1) tidak dapat digunakan untuk memperkirakan variabel penerapan pupuk organik pada tanaman bawang merah. Variabel Ketersediaan pupuk ( X2) Nilai koefisien Ketersediaan (X2) sebesar $-3,03$ atau pengaruh negatif, semakin tinggi nilai ketersediaan, maka semakin rendah nilai penerapanya setiap penambahan satu satuan pengalaman maka akan rendah penerapan pupuk organik pada tanaman bawang merah sebesar $-3,03$ satuan. Uji signifikan dengan menggunakan uji-t terhadap koefisien variabel ketersediaan pupuk (X2) didapat t-hitung sebesar 1,559 lebih kecil dari nilai $\mathrm{t}$ - tabel $\mathrm{n}=$ 26 (2,056).Karena dalam analisis menggunakan uji 2 sisi sehingga apabila nilai negatif, maka penerapan cenderung berpengaruh negatif (tidak nyata) secara umum dapat dikatakan variabel ketersediaan (X2) ada berpengaruh yang tidak nyata terhadap penerapan pupuk organik pada tanaman bawang merah, sehingga variabel ketersedian pupuk (X2) tidak dapat digunakan untuk memperkirakan variabel penerapan pupuk Organik pada tanaman bawang merah. Variabel modal usaha tani (X3).Nilai koefisien frekuensi ketersedian modal (X3) sebesar 0,609 atau setiap penambahan satu satuan pengalaman maka akan meningkat penerapan pupuk Organik pada tanaman bawang merah sebesar 0,609 satuan. Uji signifikan dengan menggunakan uji-t terhadap koefisien variabel modal usaha tani (X3) didapat t-hitung sebesar 3,727 lebih besar dari nilai t-tabel $\mathrm{n}=26(2,056)$, artinya variabel modal usaha tani (X3) berpengaruh terhadap penerapan pupuk Organik pada tanaman bawang merah, sehingga variabel modal (X3) dapat digunakan untuk perkirakan variabel penerapan pupuk Organik pada tanaman bawang merah.

Berdasarkan hasil tabulasi kajian faktor-faktor yang mempengaruhi penggunaan pupuk organik pada tanaman bawang merah di desa Murtigading kecamatan Sanden kabupaten Bantul dengan mengambil sampel responden yang menanam bawang merah terdapat tiga (3) faktor yang diuji, faktor kepercayaan, faktor ketersediaan pupuk dan faktor modal. Sampel Petani yang diambil adalah petani penggunaan pupuk organik pada tanaman bawang merah.

Berdasarkan hasil tabulasi variabel penerapan dengan nilai pencapaian $81,78 \%$ termasuk dalam kategori tinggi, hal ini menggambarkan petani sudah menerapkan penggunaan pupuk organik pada tanaman bawang merah sesuai dengan anjuran, penggunaan pupuk organic diperoleh baik yang dijual maupun dari ternak petani.

Pada faktor - faktor yang mempengaruhi penggunaan pupuk organik yang dibahas adalah faktor kepercayaan, ketersedian pupuk dan modal terhadap penerapan pupuk organik pada tanaman bawang merah .

a. Kepercayaan.

Berdasarkan dari hasil kajian diketahui bahwa tingkat capaian kepercayaan untuk petani sebanyak $76,33 \%$ termasuk dalam kategori kurang percaya. Hal ini sesuai dengan hasil wawancara dilapangan alasan mengapa petani kurang percaya bahwa pupuk organic dapat meningkatkan produktifitas bawang merah, menurut petani penggunaan 
pupuk kimia pertumbuhan lebih cepat dan hasil lebih cepat kelihatan dibandingkan dengan pupuk organic walaupun ada subsidi pupuk organik.

Pada analisis regresi berganda, kepercayaan tidak berpengaruh terhadap penerapan pupuk organic pada tanaman bawang merah, sesuai hasil dilapangan bahwa petani lebih percaya pada penggunaan pupuk kimia dibanding pupuk organic. Menurut Rousseau et al (1998), kepercayaan adalah wilayah psikologis yang merupakan perhatian untuk menerima apa adanya berdasarkan harapan terhadap perilaku yang baik dari orang lain. Kepercayaan petani didefinisikan sebagai kesediaan satu pihak untuk menerima resiko dari tindakan pihak lain berdasarkan harapan bahwa pihak lain akan melakukan tindakan penting untuk pihak yang mempercayainya, terlepas dari kemampuan untuk mengawasi dan mengendalikan tindakan pihak yang dipercaya (Mayer et al, 1995).

Berdasarkan dari hasil kajian diketahui bahwa tingkat capaian kepercayaan untuk petani sebanyak 76,33 $\%$ termasuk dalam kategori kurang percaya. Hal ini sesuai dengan hasil wawancara dilapangan alasan mengapa petani kurang percaya bahwa pupuk organic dapat meningkatkan produktifitas bawang merah, menurut petani penggunaan pupuk kimia pertumbuhan lebih cepat dan hasil lebih cepat kelihatan dibandingkan dengan pupuk organic walaupun ada subsidi pupuk organik. kepercayaan terjadi ketika seseorang yakin dengan reliabilitas dan integritas dari orang yang dipercaya (Morgan \& Hunt, 1994). Maka petani lebih percaya dengan penggunaan pupuk kimia karena hasilnya lebih cepat dan nyata.

Pada analisis regresi berganda, kepercayaan tidak berpengaruh terhadap penerapan pupuk organic pada tanaman bawang merah, sesuai hasil dilapangan bahwa petani lebih percaya pada penggunaan pupuk kimia dibanding pupuk organic, Hal yang berkaitan dengan teori yang dikemukakan Menurut Rosseau, Sitkin, dan Camere (1998), kepercayaan yaitu kesediaan seseorang untuk menerima resiko.

Maka dalam hal ini petani di desa murtigading kecamatan Sanden pada dasarnya tidak mengambil resiko dalam budidaya tanaman bawang merah, meskipun mereka mengetahui manfaat dari pupuk organic namun kepercayaan mereka lebih ke pupuk kimia yang menurut mereka lebih baik dan telah dilihat hasilnya secara nyata.

b. Ketersediaan Pupuk.

Berdasarkan hasil kajian diketahui bahwa tingkat capaian ketersediaan pupuk organic di desa murtigading Kecamatan Sanden sebanyak 87,44\% dengan kategori cukup Modal usaha tani. Berdasarkan kajian diketahui bahwa tingkat capaian modal usaha sebanyak 85,89 $\%$ dengan kategori cukup. Berdasarkan hasil wawancara dengan petani bahwa modal untuk usaha tani merupakan modal sendiri dan sebagian adalah pinjaman bank, petani memahami bahwa modal adalah hal yang penting dalam berusaha tani, hal ini sesuai dengan oleh Gilarso (1993) dalam Yani, (2016), mengemukakan bahwa modal merupakan sarana atau bekal untuk melaksanakan usaha.

Ketersediaan adalah kesiapan suatu sarana (tenaga, barang, modal, anggaran) untuk dapat digunakan atau dioperasikan dalam waktu yang telah ditentukan (KBB). Ketersediaan pupuk adalah kesiapan jumlah pupuk yang dibutuhkan dalam usaha tani untuk mencapai hasil yang maksimal. Berdasarkan hasil kajian diketahui bahwa tingkat capaian ketersediaan 
pupuk organic di desa murtigading kecamatan sanden sebanyak 87,44\% dengan kategori cukup hal ini dikarenakan bahan- bahan yang digunakan untuk pembuatan pupuk organic sangat banyak. Selain itu petani juga menerima pupuk organik bersubsidi dari pemerintah untuk pemupukan tanaman, namun pupuk tersebut belum sepenuhnya digunakan pada tanaman.

Menurut penelitian Fitri, et, al. (2014)

Pemberian pupuk organik yang berbeda berpengaruh nyata pada bobot kering umbi per sampel dan jumlah anakan umur 3 MST namun berpengaruh tidak nyata pada tinggi tanaman, rasio tajuk akar, bobot basah umbi per sampel dan jumlah siung. Pemberian pupuk organik kompos jerami meningkatkan bobot kering umbi per sampel tertinggi sebesar $36.02 \mathrm{~g}$ dibandingkan pupuk organik lainnya (Fitri, et, al., 2014).

Ketersediaan kotoran hewan yang berasal dari ternak besar dan ternak kecil pada setiap rumah tangga petani merupakan hal yang penting dalam pembuatan pupuk organik. Akan tetapi, tidak semua petani memiliki ternak, sehingga ketersediaan kotoran hewan sebagai bahan kompos tidak merata. Artinya tidak semua petani mampu menyediakan kompos sebagai pupuk organik. Ketersediaan bahan hijauan berasal dari pekarangan, luar pekarangan, dan limbah dapur setiap rumah tangga yang sedikit dinilai kurang praktis dan tidak layak operasional untuk dibuat kompos. Sebagian besar petani umumnya terkendala oleh tidak cukup tersedianya hijauan dan tidak tersedianya kotoran hewan sebagai bahan kompos (Sumarno, 2012).

Pada analisis regresi berganda, ketersediaan pupuk berpengaruh tidak nyata terhadap penerapan pupuk organic pada tanaman bawang merah, hal ini dikarenakan kurangnya pemanfaatan bahan organic sebagai pupuk dan bahan yang digunakan untuk pembuatan pupuk organic sering dijual ke desa lain alasanya pembuatan pupuk organik membutuhkan tenaga yang kuat untuk mengolah, hasil wawancara di lapangan menurut petani persediaan pupuk organic sangat kurang karena petani lebih banyak menggunakan pupuk kimia. Adanya subsidi pupuk organic oleh pemerintah juga tidak dimanfaatkan oleh petani. Meskipun ketersediaan pupuk maksimal namun petani tidak memanfaatkannya, hal ini menggambarkan bahwa ketersediaan pupuk tidak berpengaruh terhadap penerapan pupuk organik.

c. Modal usaha tani.

Dalam produksi pertanian, modal adalah peringkat ke 2 faktor produksi terpenting setelah tanah. Bahkan kadangkadang orang menyebut "modal" adalah satu-satunya milik petani yaitu tanah disamping tenaga kerja yang dinilai murah. Dalam ekonomi pertanian disebutkan pula modal adalah barang atau uang yang bersama-sama faktor produksi tanah dan tenaga kerja menghasilkan barang-barang baru atau komoditi pertanian (Mubyarto,1993). Modal petani yang berupa barang di luar tanah adalah ternak beserta kandangnya, cangkul, bajak, dan alat-alat pertanian lain, bibit, pupuk dan hasil panen yang belum dijual, tanaman yang masih di sawah dan lainnya.

Berdasarkan kajian diketahui bahwa tingkat capaian modal usaha sebanyak 85,89 \% dengan kategori cukup. Berdasarkan hasil wawancara dengan petani bahwa modal untuk usaha tani merupakan modal sendiri dan sebagian adalah pinjaman bank, petani memahami bahwa modal adalah hal yang penting dalam berusaha tani, hal ini sesuai dengan oleh Gilarso (1993) dalam Yani, (2016), mengemukakan bahwa modal merupakan sarana atau bekal untuk melaksanakan usaha. Modal dalam usahatani bersamaan 
dengan faktor produksi lainya akan menghasilkan produk. Modal ini semakin berperan dengan berkembangnya usahatani tersebut. Pada usahatani sederhana peran modal yang diperlukan kecil, namun semakin maju usahatani modal yang diperlukan semakin besar. Modal menurut fungsinya dapat dibedakan menjadi dua bagian yaitu, (a) Modal tetap (fixed capital) adalah modal yang tidak habis dalam satu kali proses produksi atau dapat dipakai berkali-kali dalam proses produksi. (b) Modal tidak tetap (modal lancar) adalah modal yang habis dalam satu kali proses produksi, contohnya bibit, pupuk, obat pemberantas hama dan penyakit. Menurut jenisnya modal usahatani berasal dari modal sendiri dan modal pinjaman. (a) Modal sendiri adalah modal yang dikeluarkan petani itu sendiri yang berasal dari tabungan atau sisa dari hasil usahatani sebelumnya. (b) Modal pinjaman adalah modal yang didapat petani diluar pendapatan usahatani. Pinjaman usahatani yaitu berupa kredit formal dan kredit non formal dan kemitrausahaan (Manurung, 1998; dalam Yani, 2016). Faktor modal memegang peranan penting yang dipertimbangkan petani sebelum melakukan usahatani (Hermanto, 1992; dalam Yani, 2016). Modal diperlukan terutama untuk pengadaan sarana produksi (benih, pupuk dan pestisida), yang dirasakan petani semakin tinggi harganya. Sumber dana yang berasal dari rumah tangga petani sering dipandang tidak cukup untuk membiayai peningkatan usahataninya. Karena pada umumnya rumah tangga petani di Indonesia adalah petani kecil dan bermodal lemah. Pada analisis regresi berganda, modal berpengaruh nyata terhadap penerapan pupuk organic pada tanaman bawang merah. Kenyataan dilapangan pengaruh modal sangat besar dalam berusaha tani, menurut petani modal adalah pendukung utama dalam suatu usaha, jika tidak ada modal maka akan berdampak pada kebutuhan petani dalam memenuhi kebutuhan taninya, salah satunya adalah pupuk. Hal ini sesuai dengan yang dikemukakan Gilarso (1993), mengemukakan bahwa modal merupakan sarana atau bekal untuk melaksanakan usaha.

Secara ekonomi modal adalah barang-barang yang bernilai ekonomi yang digunakan untuk menghasilkan tambahan kekayaan ataupun untuk meningkatkan produksi. Modal dalam usahatani bersamaan dengan faktor produksi lainya akan menghasilkan produk. Modal ini semakin berperan dengan berkembangnya usahatani tersebut. Pada usahatani sederhana peran modal yang diperlukan kecil, namun semakin maju usahatani modal yang diperlukan semakin besar.

\section{KESIMPULAN DAN SARAN}

Tingkat penerapan pupuk organik pada tanaman bawang merah termasuk dalam kategori tinggi atau menerapkan. Pencapaian nilai kepercayaan termasuk dalam kategori sedang atau kurang percaya. Sedangkan ketersediaan dan modal termasuk dalam kategori tinggi. Secara bersama variabel kepercayaan, ketersediaan dan modal berpengaruh nyata terhadap penerapan pupuk organik pada tanaman bawang merah. Dari ke 2 faktor yaitu Faktor kepercayaan ketersediaan tidak berpengaruh nyata terhadap penerapan pupuk organik pada tanaman bawang merah, dan modal usaha tani berpengaruh nyata terhadap penerapan pupuk organik pada tanaman bawang merah .

\section{DAFTAR PUSTAKA}

Ayesma. (2014). Revolusi Hijau di Desa Kemantan Kebalai Kecamatan Air Hangat Timur Kabupaten Kerinci Dan Perubahan Terhadap Kehidupan Petani (1969-1998). Jurnal Program 
Studi Pendidikan Sejarah, STKIP PGRI Sumatera Barat.

Bahrul Ulum. (2006). Analisis FaktorFaktor Yang Mempengaruhi Persepsi dan Sikap Masyarakat Terhadap Penggunaan Pupuk Organik. Abstrak. Fakultas Sains dan Teknologi UIN Syarif Hidayatullah Jakarta. Hal. 4.

Erita Hayati, T. Mahmud, dan R. Fazil . (2012). "Pengaruh Jenis Pupuk Organik Dan Varietas Terhadap Pertumbuhan Dan Hasil Tanaman Cabai (Capsicum Annum L.)". J. Floratek 7: $173-181$.

Firmansyah, I, Liferdi, Khaririyatun, N, dan Yufdy. 2015. Pertumbuhan dan Hasil Bawang Merah dengan Aplikasi Pupuk Organik dan Pupuk Hayati pada Tanah Aluvial. J. Hort. Vol. 25 (2):133-141.

Fitri, A., R. Sipayung., C. Hanum. (2014). Pertumbuhan dan Produksi Bawang Merah dengan Pemberian Berbagai Pupuk Organik. Jurnal Online Agroekoteknologi. Maret Vol 2 (2): 482- 496.

Hartatik dan Widowati. (2010). Pupuk Organik.http://balittanah.litbang.dept an.go.id/dokumentasi/buku/pupuk/pu puk4.pdf.

Jefianty. (2012). Perceptions of the Highlands Vegetable Farmers Organic Fertilizer in Rurukan Village Sub District East Tomohon. Under the guidance Octavianus Porajouw as chairman, and Johnny A. Tuyuwale and Caroline B.D. Pakasi as members. Jurnal: Jurusan Sosial Ekonomi, Fakultas Pertanian Universitas Sam Ratulangi Manado.

Kementan. (2016). Rencana Strategis Kementerian Pertanian Tahun 20152019. Jakarta: Kementerian Pertanian. Hal 4.

Lawalata, M. (2015). Efisiensi Relatif Usahatani Bawang Merah di Kabupaten Bantul dengan Pendekatan
Data Envelopment Analysis (DEA). Jurnal: Fakultas Ekonomi Pertanian UGM Yogyakarta. Hal 1.

Mardikanto, T. (2009). Penyuluhan Pembangunan Pertanian. Sebelas Maret University Press. Surakarta.

Prihmantoro, H. (1996). Memupuk Tanaman Sayur. PT Penebar Swadaya. Hal 5. Roidah, Syamsu. 2013. Manfaat Penggunaan Pupuk Organik Untuk Kesuburan Tanah. Jurnal Universitas Tulungagung Bonorowo, 1 (1): 30 - 42

Sarief, Saifuddin. (1986). Kesuburan dan Pemupukan Tanah Pertanian. Pustaka Buana. Bandung.

Setyamidjaja, D. (1986). Pupuk dan Pemupukan. CV. Simplex. Jakarta. Hal 29 Shinta, 2011. Ilmu Usaha Tani. UB Press. Malang

Soekartawi, A. Soeharjo, J. L. Dillon, \& J. B. Hardaker. (1986). Ilmu Usaha Tani dan Penelitian untuk Pengembangan Petani Kecil. Universitas IndonesiaPress. Jakarta.

Sugiyono. (2010). Statistik Nonparametris Untuk Penelitian. Alfa Beta. Jakarta. Sugiyono. 2013. Metode Penelitian Pendidikan. Alfabeta. Bandung.

Sujono. (2013). Metode penyuluhan Pertanian.CV. Prineka Yogyakarta.

Sujono. (2016). Tingkat Pemberdayaan Kelembagaan Petani Melalui PUAP Di Kabupaten Bantul

Sujono. Yahya, Mukhlis. (2017). Pelaksanaan Penyuluhan Pertanian. Pusat Pendidikan Pertanian. Badan Penyuluhan dn Pengmbngn Sumerdaya Manusia Pertanian.

Sujono. (2018). Studi Banding Upaya Pemberdayaan Petani. CV.Prineka.Yogyakarta

Sujono. (2018). Proses Pembelajaran Orang Dewasa. Buletin Diklat Provinsi Yogyakarta.

Sujono. (2018). Ketepatan Pemilihan Metode Penyuluhan sebagai Proses Pembelajaran Petani. Bulletin Diklat 
Provinsi Yogyakarta.

Suriadikarta dan Simanungkalit. (2006). Pupuk Organik Dan Pupuk Hayati Organic Fertilizer And Biofertilizer. Balai Besar Penelitian dan Pengembangan Sumberdaya Lahan Pertanian. Bogor. Hal 2.

Sutanto R. (2002). Pertanian Organik Menuju Pertanian Alternatif dan Berkelanjutan. Kanisius. Yogyakarta. Hal. 5

Sutanto, R. (2002). Penerapan Pertanian Organik. Kanisius. Yogyakarta.
Sutedjo,M. 2010. Pupuk dan Cara Pemupukan. Penerbit Rineka Cipta.Jakarta.

Suwandi, (2014). Budidaya Bawang Merah di Luar Musim Teknologi Unggulan Mengantisipasi Dampak Perubahan Iklim. IAARD Press. Bogor.

\section{DOI :}

